\title{
One-Pot Synthesis of 1,8-Dioxodecahydroacridines and Polyhydroquinoline using 1,3-Di (bromo or chloro)-5,5-Dimethylhydantoin as a Novel and Green Catalyst under Solvent-Free Conditions
}

\author{
Behrooz Maleki, ${ }^{*}$ Reza Tayebee, Mina Kermanian, and Samaneh Sedigh Ashrafi \\ Department of Chemistry, Hakim Sabzevari University, Sabzevar 96179-76487, Iran. b.maleki@hsu.ac.ir
}

Received March 12, 2013; Accepted May 29, 2013.

\begin{abstract}
Solvent-free, one-pot synthesis of polyhdroquinoline and 1,8-dioxodecahydroacridine derivatives have been described via Hantzsch condensation of various aldehydes, ammonium acetate with (i) cyclic 1,3-dicarbonyl compounds and ethyl acetoacetate and (ii) cyclic 1,3-dicarbonyl compounds ( 2 mmoles) in a very simple, efficient, and environmentally benign method using 1,3-(dibromo or dichloro)5,5-dimethylhydantoin as a cheap, non-toxic and neutral catalyst with up to excellent yields.

Keywords: Aldehydes, cyclic 1,3-dicarbonyl compounds, ammonium acetate, ethyl acetoacetate, green catalyst, solvent-free conditions, onepot synthesis.
\end{abstract}

\section{Introduction}

The development of multi-component reactions (MCRs) designed to produce elaborate biologically active compounds has become an important area of research in organic, combinatorial, and medicinal chemistry [1]. One-pot multicomponent reaction strategies offer significant advantages over conventional lineartype syntheses by virtue of their convergence, productivity, facile execution and high yields [2].

The development of new methods for the synthesis of 4-substituted 1,4-dihydropyridine (DHP) is an important area of synthetic research because of the broad spectrum of their biological and pharmaceutical properties such as antidiabetic, hepatoprotective, vasodilator, geroprotective, antiatherosclerotic, bronchodilator, and antitumor [3]. Cardiovascular agents such as nifedipine, nicardipine, amlodipin and other related derivatives are dihydropyridyl compounds, which are effective for the treatment of hypertensive [4] (Fig. 1).

Current studies reveal that 1,4 dihydropyridine exhibits several medicinal applications which include neuroprotectant [5], platelet antiaggregatory activity [6], cerebral antischemic activity in treatment of alzheimer's diasease [7], and chemo-
Resumen. Se describe la síntesis en un paso, libre de disolvente, de derivados de polihidroquinolina y 1,8-dioxodecahidroacridina mediante la condensación de Hantzch de diversos aldehídos y acetato de amonio con (i) compuestos 1,3-dicarbonílicos cíclicos y acetoacetato de etilo y (ii) compuestos 1,3-dicarbonílicos cíclicos (2 equiv) empleando un método simple, eficiente y respetuoso del medio ambiente con 1,3(dibromo o dicloro)-5,5-dimetilhidantoína como catalizador barato, no-tóxico y neutro con rendimientos excelentes.

Palabras clave: Aldehídos, compuestos 1,3-dicarbonílicos cíclicos, acetato de amonio, acetoacetato de etilo, catalizador verde, condiciones libres de disolvente, síntesis en un paso.

sensitizer acting in tumor therapy [8]. In addition, the dihydropyridines unit has been widely employed as a hydride source for reductive amination [9].

In recent years, much attention has been directed towards the synthesis of 4-substituted 1,4-dihydropyridine compounds. In 1882, Arthur Hantzch reported first synthesis of substituted 1,4-dihydropyridines by one-pot condensation of ethylacetoacetate, aldehyde and ammonia. The reaction was conducted in acetic acid or in refluxing ethanol [10]. However, these methods suffer from drawbacks such as long reaction time, the use of a large quantity of volatile organic solvents, harsh refluxing conditions and lower yields. Thus, chemists have developed several alternative and more efficient methods for the synthesis of polyhydroquinoline and 1,8-dioxodecahydroacridine derivatives which include the use of microwave irradiation [11], $\mathrm{HClO}_{4} \cdot \mathrm{SiO}_{2}$ [12], molecular iodine [13], ionic liquids [14], $\mathrm{NH}_{4} \mathrm{Cl}$ or $\mathrm{Zn}(\mathrm{OAc})_{2}$ [15], organocatalysts [16], scolecite [17], HY-zeolite [18], $p$-TSA [19], montmorillonite K10 clay [20], hafnium (IV) bis(perfluorooctanesulfonyl)imide complex [Hf( $\left(\mathrm{NPf}_{2}\right)_{4}$ ] [21], $\mathrm{ZrCl}_{4}$ [22], 5-pyrrolidin-2-yltetrazole [23], ceric ammonium nitrate (CAN) [24], silica sulfuric acid [25], triflate salts [26], $\mathrm{K}_{7}\left[\mathrm{PW}_{11} \mathrm{CoO}_{40}\right]$ [27], sulfamic acid [28], so-

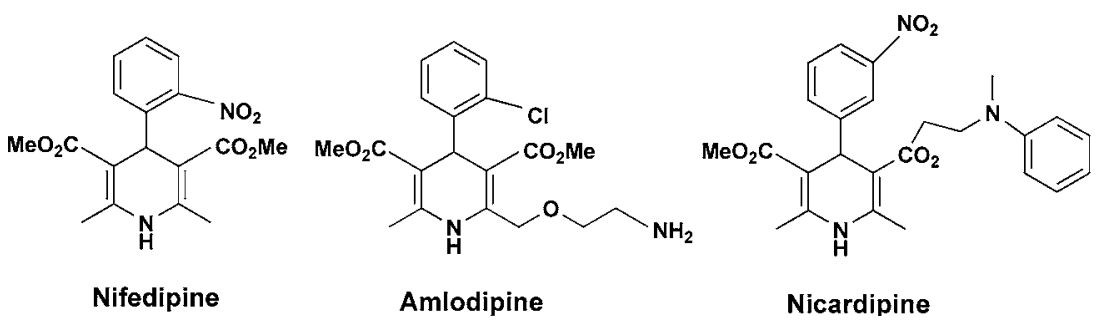

Fig. 1. Typical dihydropyridine drugs. 
lar thermal energy [29], carbon-based solid acid (CBSA) [30], $\mathrm{ZnO}$ [31], HCM-41 [32] and fluoro alcohols (TFE or HFIP) [33]. But some of those methods still have their own limitations in terms of yields, long reaction time, acidic or basic catalysis, tedious or difficult work-up, anhydrous organic solvents. In some cases, catalysts are expensive and harmful to environment. Thus, the development of a simple and efficient method for the synthesis of polyhydroquinoline and 1,8-dioxodecahydroacridine derivatives is an active area of research and there is scope for further improvement involving milder reactions and higher product yield.

\section{Results and Discussion}

$\mathrm{N}$-Halo compounds are versatile reagents and have been employed as potentially reactive intermediates that are widely used in organic synthesis. The exploitation of reagents for developing new synthetic methods is an art and constitutes a challenging process in organic chemistry. Consequently, considerable efforts have been made over the years to find newer reagents, which can minimize the drawbacks of those presently in use [34].

In recent years, 1,3-dihalo-5,5-dimethylhydantoin (DBH: I and DCH: II, Fig. 2) have been used as catalysts in organic synthesis [35]. Because these compounds are relatively nontoxic, easy to handle, low cost, green and possess good stability. 1,3-dihalo-5,5-dimethylhydantoin (I and $\mathbf{I I}$ ) have been known

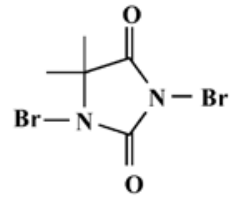

I

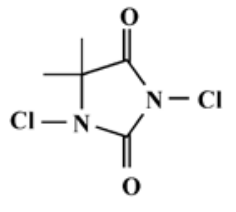

II
Fig. 2. 1,3-Di (bromo or chloro)-5,5-dimethylhydantoin. for many years as efficient substitutes for classic halogenating agents such as: $N$-chlorosuccinimide (NCS) [36], $N$-bromosuccinimide (NBS) and $N$-bromoacetamid (NBA) [37].

Organic synthesis in the absence of a solvent is a powerful tool for the generation of structurally diverse molecules. Solvent-free reactions often have special selectivity, are easy to set-up and work-up which are faster, These features have aroused great interest [38]. These aspects, coupled with the lower overall costs of running a reaction without solvent and no specially needed equipment, could become a decisive factor in industry. As a part of our interest in the development of heterocycle-based compounds [39] and also, in continuation of our work on applications of DBH [40], we first examined the catalytic role of DBH and DCH in synthesis of polyhydroquinoline and 1,8-dioxodecahydroacridine derivatives via multi-component condensation of aldehydes, ammonium acetate with (i) 1,3-cyclic compound (dimedone or 1,3-cyclohexanediones) and ethyl acetoacetate (ii) 2 moles of 1,3-cyclic compound (dimedone or 1,3-cyclohexanediones), respectively, in the presence of catalytic amounts of DBH or DCH under solvent-free condition at $130{ }^{\circ} \mathrm{C}$ (Scheme 1).

First, to investigate the feasibility of this synthetic methodology for polyhydroquinoline derivatives, the reaction was carried out simply by mixing 4-chlorobenzaldehyde (1b, $1 \mathrm{mmol})$, dimedone $(2,1 \mathrm{mmol})$, ethyl acetoacetate $(3,1 \mathrm{mmol})$, and ammonium acetate $(1.2 \mathrm{mmol})$ under solvent-free condition in the presence of $10 \mathrm{~mol} \%$ of $\mathrm{DBH}$. The mixture was stirred at $130{ }^{\circ} \mathrm{C}$ for $30 \mathrm{~min}$ and corresponding product was obtained in $94 \%$ yield. Encouraged by this result, we have changed the amount of DBH and temperature of the reaction. The results are summarized in Table 1.

An increase in the quantity of DBH from $5 \mathrm{~mol} \%$ to 10 mol\% not only decreased the reaction time from $180 \mathrm{~min}$ to 30 $\mathrm{min}$, but also increased the product yield slightly from 82 to 94 (entry 1,2). Although the use of $15 \mathrm{~mol} \%$ of DBH permitted the reaction time to decrease to $25 \mathrm{~min}$, the yield unexpectedly decreased to $52 \%$ (entry 3 ). A possible explanation for the low

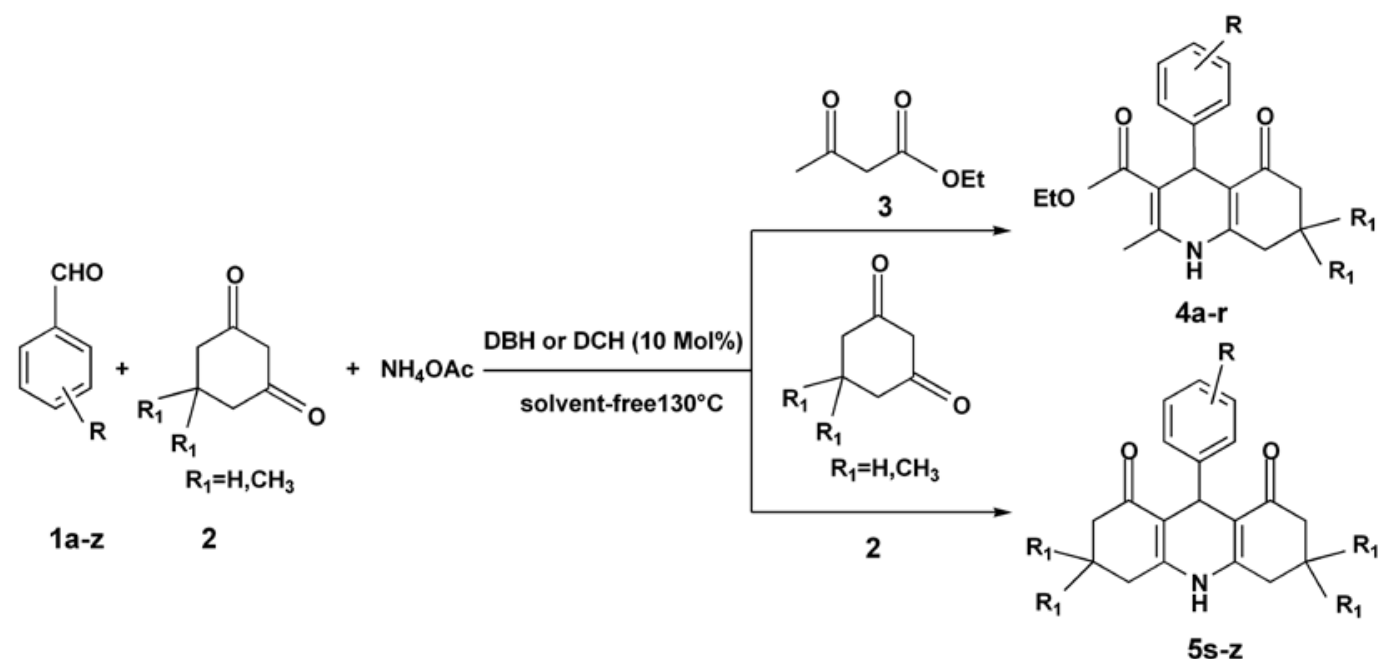

Scheme 1. One-pot synthesis of polyhydroquinoline and 1,8-dioxodecahydroacridine derivatives using DBH or DCH. 
Table 1. Optimizing the Reaction Conditions.

\begin{tabular}{ccccc}
\hline Entry & $\begin{array}{c}\text { Catalyst } \\
(\mathrm{mol} \mathrm{\% )})\end{array}$ & $\begin{array}{c}\text { Temperature } \\
\left({ }^{\circ} \mathrm{C}\right)\end{array}$ & $\begin{array}{c}\text { Time } \\
(\mathrm{min})\end{array}$ & $\begin{array}{c}\text { Yield } \\
(\%)^{\mathrm{a}}\end{array}$ \\
\hline 1 & 5 & 130 & 180 & 82 \\
2 & 10 & 130 & 30 & 94 \\
3 & 15 & 130 & 25 & 52 \\
4 & 10 & 120 & 60 & 83 \\
5 & 10 & 110 & 80 & 70 \\
6 & 10 & 140 & 30 & 56 \\
7 & 10 & 25 & 180 & 12 \\
8 & $10^{\mathrm{b}}$ & 130 & 30 & 92 \\
9 & - & 130 & 30 & - \\
10 & $10^{\mathrm{c}}$ & 130 & 40 & 82 \\
\hline
\end{tabular}

assolated yields.

${ }^{b}$ DCH used in reaction condition.

${ }^{\mathrm{C}} \mathrm{NBS}$ used in reaction condition.

product yield is that the starting material or the product may have been destroyed during the reaction when excess amount (15 $\mathrm{mol} \%$ ) of DBH was used in the exothermic reaction and that $10 \mathrm{~mol} \% \mathrm{DBH}$ was sufficient to catalyze the reaction effectively. When we carried out the reaction in $\mathrm{DBH}$ at room temperature, the reaction proceeded very slowly to give very poor yields (entry 7). We then screened the reaction condition by DCH. Interestingly, almost similar yields were achieved when DCH was used as catalyst (entry 8). As shown in Table 1, nearly no polyhydroquinoline could be detected in the absence of DBH (entry 9). Also, this reaction carried out in the presence of $\mathrm{N}$-bromosuccinimide (NBS) as catalyst at $130{ }^{\circ} \mathrm{C}$. The reaction proceeds in $40 \mathrm{~min}$ to give $82 \%$ yield (entry 10 ).

Using this optimized condition, a wide range aldehydes, ethylacetoacetate, 1,3-cyclic compound (dimedone or 1,3-cyclohexandione) and ammonium acetate were subjected to this procedure to afford the corresponding product in high to excellent yield (Table 2). The scope and generality of this fourcomponent coupling one-pot synthesis of polyhydroquinoline derivatives through Hantzsch reaction is illustrated with different aldehydes (Table 2 ). All the reactions proceeded efficiently within $25-50$ minutes at $130{ }^{\circ} \mathrm{C}$ to provide the corresponding polyhydroquinoline derivatives in excellent yields ranging from $80 \%$ to $94 \%$. This method has the ability to tolerate a variety of functional groups such as methoxy, methyl, nitro, hydroxyl, halides, etc, under the reaction conditions. Both, the electronrich and electron-deficient aldehydes as well as heterocyclic aldehyde worked well, loading to high yields of products. The structures of all the products were established from their spectral data.

After successfully synthesizing a series of polyhydroquinoline derivatives in excellent yields, we turned our attention towards the synthesis of 1,8-dioxodecahydroacridine derivatives via reaction with 2 equivalents of cyclic 1,3-dicarbonyl compounds (dimedone or 1,3-cyclichexadione), aldehydes and ammonium acetate (Scheme 1, Table 2). As expected,
Table 2. Preparation of Polyhydroquinoline and 1,8-Dioxodecahydroacridine Derivatives using DBH or DCH as Catalyst.

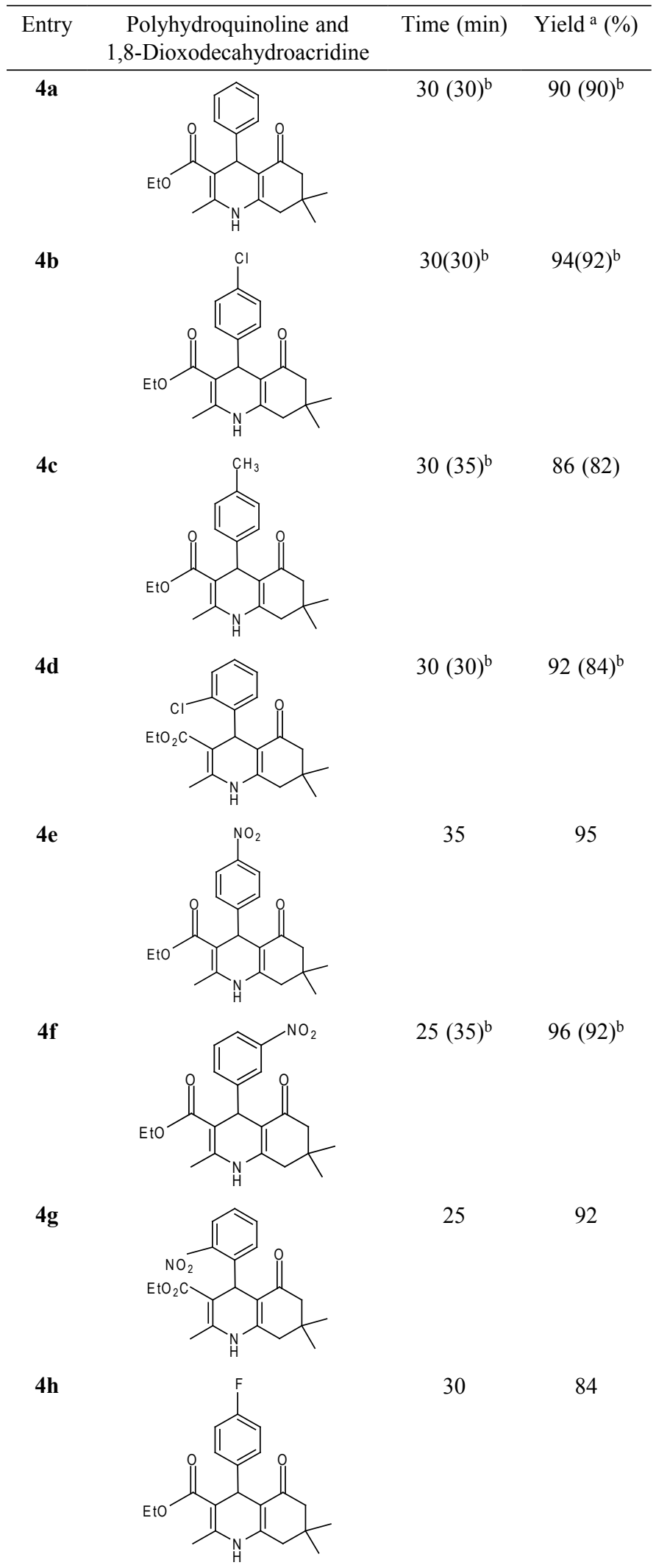


Table 2. Continues.

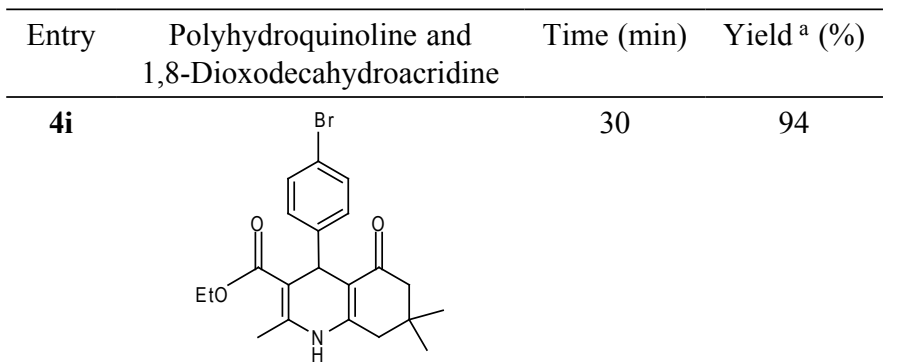

$4 \mathbf{j}$<smiles>CCOC(=O)C1=C(C)NC2=C(C(=O)CC(C)(C)C2)C1c1cccc(OC)c1</smiles>

$4 k$<smiles>COC(=O)C1=C(C)NC2=C(C(=O)CC(C)(C)C2)C1c1ccccc1OC</smiles>

41<smiles>CCOC(=O)C1=C(C)NC2=C(C(=O)CC(C)(C)C2)C1c1cccs1</smiles>

$4 m$<smiles>CCOC(=O)C1=C(C)NC2=C(C(=O)CC(C)(C)C2)C1c1ccco1</smiles>

4n<smiles>CCOC(=O)C1=C(C)NC2=C(C(=O)CCC2)C1c1ccccc1</smiles>

$40(50)^{\mathrm{b}} \quad 80(80)^{\mathrm{b}}$

40<smiles>CCOC(=O)C1=C(C)NC2=C(C(=O)CCC2)C1c1ccc(Cl)cc1</smiles>

50

94<smiles>CCOC(=O)C1=C(C)NC2=C(C(=O)CCC2)C1c1ccc([N+](=O)[O-])cc1</smiles>

Table 2. Continues.

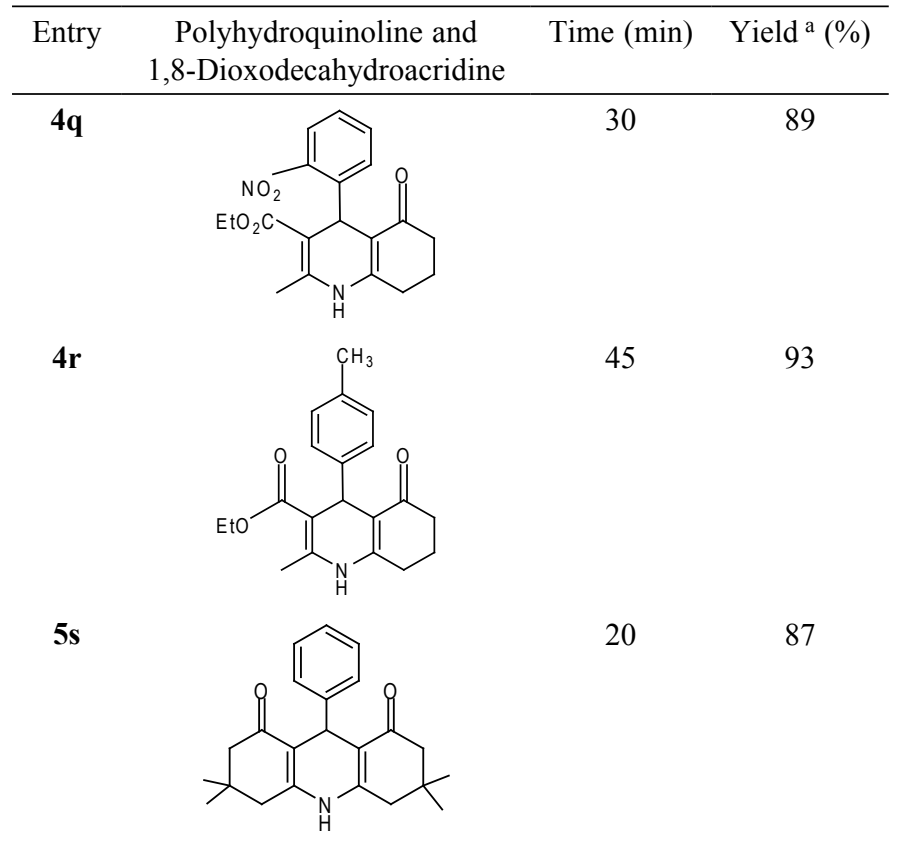

$5 t$<smiles>CC1(C)CC(=O)C2=C(C1)NC1=C(C(=O)CC(C)(C)C1)C2c1ccc(Cl)cc1</smiles>

$20(35)^{b}$

$92(90)^{\mathrm{b}}$

$5 \mathbf{u}$<smiles>Cc1ccc(C2C3=C(CC(C)(C)CC3=O)NC3=C2C(=O)CC(C)(C)C3)cc1</smiles>

$5 v$<smiles>CC1(C)CC(=O)C2=C(C1)NC1=C(C(=O)CC(C)(C)C1)C2c1ccccc1</smiles>

$5 w$<smiles>CC1(C)CC(=O)C2=C(C1)NC1=C(C(=O)CC(C)(C)C1)C2c1ccc([N+](=O)[O-])cc1</smiles>

$5 \mathbf{x}$<smiles>CC1(C)CC(=O)C2=C(C1)NC1=C(C(=O)CC(C)(C)C1)C2c1cccc([N+](=O)[O-])c1</smiles> 
Table 2. Continues.

\begin{tabular}{llll}
\hline Entry & $\begin{array}{c}\text { Polyhydroquinoline and } \\
\text { 1,8-Dioxodecahydroacridine }\end{array}$ & Time (min) & Yield $^{\text {a }}(\%)$ \\
\hline $5 y$ & 25 & \\
\hline $5 z$
\end{tabular}

assolated yields.

${ }^{b} \mathrm{DCH}$ used in reaction condition.

these substrates underwent smooth, one-pot conversion to give the corresponding 1,8-dioxodecahydroacridines $\mathbf{5 s - z}$ in good yields.

Regarding the mechanism of the reactions which are catalyzed by DBH or DCH [35], a plausible mechanism for the formation of polyhydroquinoline and 1,8-dioxodecahydroacridine derivatives is proposed in Scheme 2. According to this mechanism, polyhydroquinoline 4a-r may be formed either through steps I-III or through steps IV-VI. Also, the formation of $\mathbf{5 s - z}$ takes place through a Hantzsch-like mechanism via conjugate addition of the enamine intermediate (obtained from dimedone and ammonium acetate, step $\mathbf{V}$ ) to the corresponding product (obtained from dimedone and aldehydes 1a-z, step I) followed by imino-enamino tautomerism and subsequent cyclization.

In order to show efficiency of this method, we compared the results of the DBH or DCH catalyzed synthesis of polyhydroquinoline and 1,8-dioxodecahydroacridine derivatives with those of several catalysts that have been recently published in the literature. As shown in Table 3, DBH or DCH, as a heterogeneous and green catalyst, is more efficient than most of the catalysts in terms of reaction time and yield are comparable to the others, which are not commercially available and must be synthesized.

\section{Conclusion}

In conclusion, we have demonstrated that $\mathrm{DBH}$ or $\mathrm{DCH}$ is a highly efficient catalyst for the synthesis of polyhydroquinoline and 1,8-dioxodecahydroacridines derivatives under solventfree conditions and low catalyst loading. In addition moisture compatibility of the catalyst, good to excellent yields of products, short reaction time, ,simple environmental and isolation procedures make this methodology a valid contribution to the existing processes in the field of polyhydroquinoline and 1,8dioxodecahydroacridines derivatives synthesis. The process does not require the use of any volatile organic solvent, tedious work-up, strongly acidic conditions, metal catalyst and thus, is a simple, cleaner, easy, environmentally-friendly and safety reaction.

\section{Experimental}

\section{General}

IR spectra were recorded on a Shimadzu 435-U-04 spectrophotometer ( $\mathrm{KBr}$ pellets). ${ }^{1} \mathrm{H}$ and ${ }^{13} \mathrm{C}$ NMR spectra were obtained using Bruker DRX-300 Avance spectrometer in DMSO- $\mathrm{d}_{6}$ or $\mathrm{CDCl}_{3}$ using TMS as an internal reference. Melting points were determined in open capillary tubes in a Stuart BI Branstead Electrothermal Cat No:IA9200 apparatus and uncorrected.

Typical Procedure for the Synthesis of Polyhydroquinoline and 1,8-Dioxodecahydroacridine Derivatives

(i) Synthesis of Ethyl-1,4,7,8-tetrahydro-2,7,7-trimethyl-4-(4chlorophenyl)5-(6H)-oxoquinoline-3-carboxylate (4b). A mixture of 4-chlorobenzaldehyde (1), $1 \mathrm{mmol})$, dimedone (2, 1 $\mathrm{mmol})$, ethyl acetoacetate $(\mathbf{3}, 1 \mathrm{mmol})$, ammonium acetate $(1.2$ $\mathrm{mmol})$ and $\mathrm{DBH}$ or $\mathrm{DCH}(10 \mathrm{~mol} \%)$ was heated on an oil bath at $130{ }^{\circ} \mathrm{C}$ for $30 \mathrm{~min}$. Completion of the reaction was indicated by TLC (hexane:ethyl acetate, 2:1), after completion, appropriate amount of hot EtOH (96\%) was added and the mixture stirred for $10 \mathrm{~min}$. Then, the catalyst was separated by filtration. The filtrate was poured into crushed ice and the solid product, which separated was filtered and recrystallized from ethanol to get pure ethyl-1,4,7,8-tetrahydro-2,7,7-trimethyl-4-(4-chlorophenyl)5-(6H)-oxoquinoline-3-carboxylate $(\mathbf{4 b})$.

(ii) Synthesis of 3,3,6,6-Tetramethyl-9-(4-chloro-phenyl)1,2,3,4,5,6,7,8-octahydroacridine-1,8-dione (5t). In a separate set of experiments, a mixture of 4-chlorobenzaldehyde (1), $1 \mathrm{mmol})$, dimedone $(2,1 \mathrm{mmol})$, ethyl acetoacetate $(3,1 \mathrm{mmol})$, ammonium acetate $(1 \mathrm{mmol})$ and DBH or DCH $(10 \mathrm{~mol} \%)$ was added and the mixture was heated on an oil bath at $130{ }^{\circ} \mathrm{C}$ for $20 \mathrm{~min}$. These reactions were all repeated exactly under same conditions described above. The results obtained are showed in Table 2.

All the products are known, characterized by IR, NMR spectral analysis and compared with the authentic samples. Melting points of compounds are consistent with reported values.

Melting points for polyhydroquinoline and 1,8-dioxodecahydroacridine derivatives: 4a, mp (200-202 [12] 203-204); 4b, mp (243-245 [12], 245-246); 4c, mp (258-260 [12], 260-261); 4d, mp (207-210 [12], 208-210); 4e, mp (239-241, ref. 12, 242244); 4f, mp (177-179 [12], 178-179); 4g, mp (205-207 [12], 206-207); 4h, mp (185-186 [12], 185-186); 4i, mp (249-250 [12], 252-253); 4j, mp (199-200 [32], 202-204); 4k, mp (192193 [16c], 193-195); 4l, mp (239-241 [12], 238-240); 4m, mp (248-250 [12], 246-248); 4n, mp (240-242 [13], 240-241); 4o, mp (234-236 [13], 234-235); 4p, mp (200-202 [13], 204-205); 4q, mp (191-192 [13], 190-191); 4r, mp (240-242 [13], 240- 

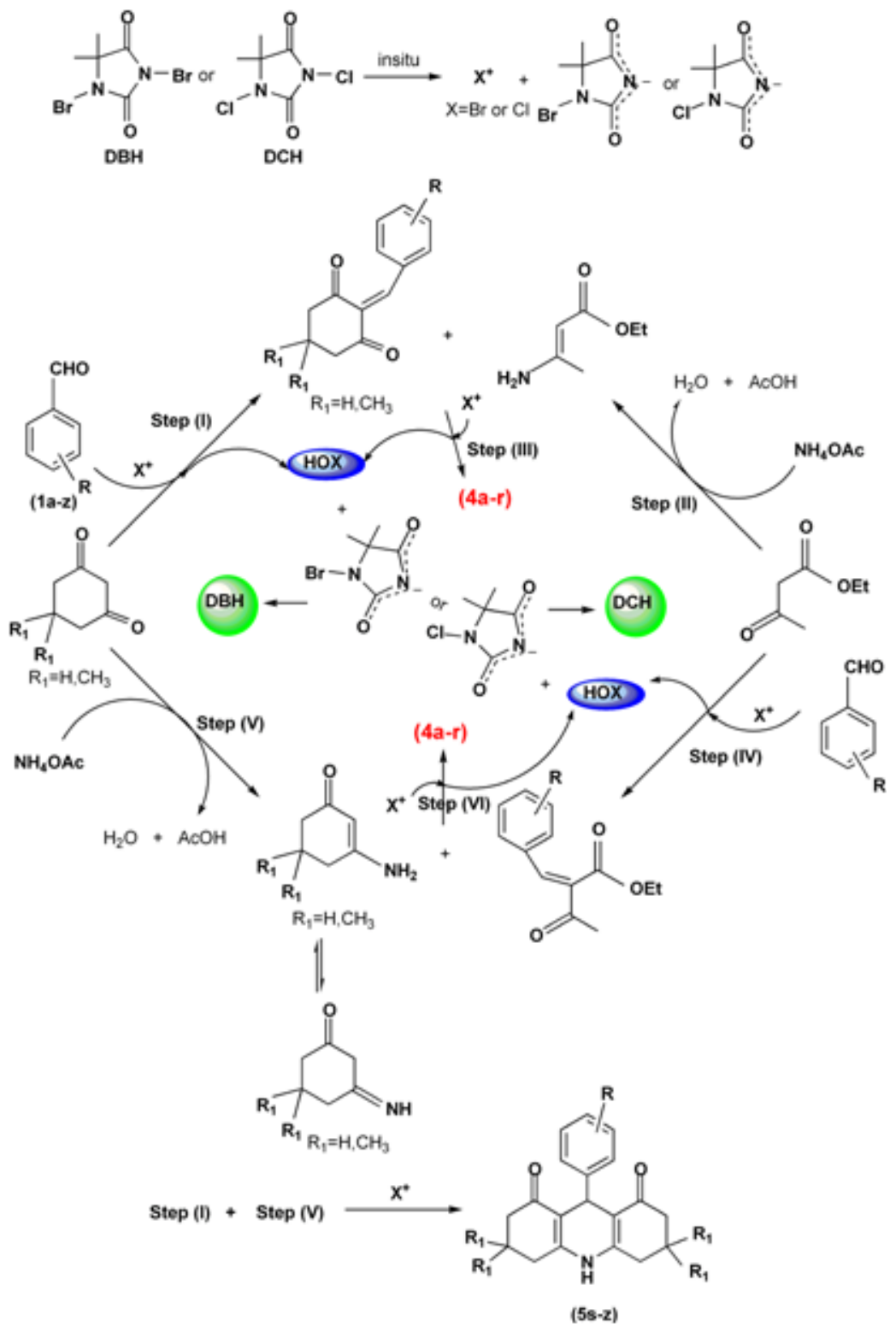

Scheme 2. Proposed reaction mechanisms.

241); 5s, mp (192-194 [13], 190-192); 5t, mp (297-300 [30], 299-301); 5u, mp (268-270 [30], 269-270); 5v, mp (220-222 [30], 220-222); 5w, mp (288-290 [30], 286-289); 5x, mp (285288 [30], 288-291); 5y, mp (276-278 [33], 279-281); 5z, mp (265-267 [33], 268-270).

\section{Analytical data for selected compounds}

Ethyl-1,4,7,8-tetrahydro-2,7,7-trimethyl-4-(3-methoxyphenyl)5-(6H)-oxoquinoline-3-carboxylate (4j): ${ }^{1} \mathrm{H}$ NMR (300 MHz, DMSO-d $)_{6} \delta 0.85(\mathrm{~s}, 3 \mathrm{H}), 0.99(\mathrm{~s}, 3 \mathrm{H}), 1.13(\mathrm{t}, 3 \mathrm{H})$, 1.94-2.43 (m, 7H), 3.65 (s, 3H), 4.00 (q, 2H), 4.81 (s, 1H), 6.62$7.18(\mathrm{~m}, 4 \mathrm{H}), 9.05\left(\mathrm{~s}, 1 \mathrm{H}, \mathrm{NH}\right.$, exchangeable with $\left.\mathrm{D}_{2} \mathrm{O}\right) ;{ }^{13} \mathrm{C}$ NMR (75 MHz, DMSO-d 6 ) $\delta 14.61,18.57,26.78,29.59,26.19$, $50.58,55.17,59.42,104.16,110.15,111.10,114.06,120.23$, $129.40,145.37,149.49,150.65,159.28,167.55,195.60$; IR
(KBr disc) $\mathrm{cm}^{-1}: 3233,3080,2965,1696,1612,1490,1384$, $1284,1220,710$.

Ethyl-4-(4-methylphenyl)-2-methyl-5-oxo-1,4,5,6,7,8hexahydroquinoline-3-carboxylate (4r): ${ }^{1} \mathrm{H}$ NMR $(300 \mathrm{MHz}$, $\left.\mathrm{CDCl}_{3}\right) \delta 1.18(\mathrm{t}, 3 \mathrm{H}), 1.86-1.98(\mathrm{~m}, 2 \mathrm{H}), 2.25-2.38(\mathrm{~m}, 10 \mathrm{H})$, $4.03(\mathrm{q}, 2 \mathrm{H}), 5.05(\mathrm{~s}, 1 \mathrm{H}), 6.93(\mathrm{~s}, 1 \mathrm{H}, \mathrm{NH}$, exchangeable with $\left.\mathrm{D}_{2} \mathrm{O}\right), 6.99-7.01(\mathrm{~d}, 2 \mathrm{H}), 7.17-7.20(\mathrm{~d}, 2 \mathrm{H}) ;{ }^{13} \mathrm{C}$ NMR $\left(75 \mathrm{MHz}, \mathrm{CDCl}_{3}\right) \delta 14.19,19.13,21.02,27.15,35.88,37.06$, 59.32, 59.73, 105.90, 113.07, 127.76, 128.58, 135.37, 143.60, 144.37, 150.63, 167.57, 197.07; IR ( $\mathrm{KBr}$ disc) $\mathrm{cm}^{-1}: 3233$, $3073,2985,1684,1610,1486,1394,1280,1230,1084$, 710 .

3,3,6,6-Tetramethyl-9-(phenyl)-1,2,3,4,5,6,7,8-octahydroacridine-1,8-dione (5s): ${ }^{1} \mathrm{H} \mathrm{NMR}\left(300 \mathrm{MHz}, \mathrm{CDCl}_{3}\right) \delta 0.95$ (s, 6H), 1.09 (s, 6H), 2.11-2.32 (m, 8H), 5.10 (s, 1H), 7.04-7.35 $(\mathrm{m}, 5 \mathrm{H}), 7.83$ (brs, $1 \mathrm{H}, \mathrm{NH}$, exchangeable with $\left.\mathrm{D}_{2} \mathrm{O}\right) ;{ }^{13} \mathrm{C}$ 
Table 3. Comparison of Methods for the Synthesis of Polyhydroquinoline and 1,8-dioxodecahydroacridine.

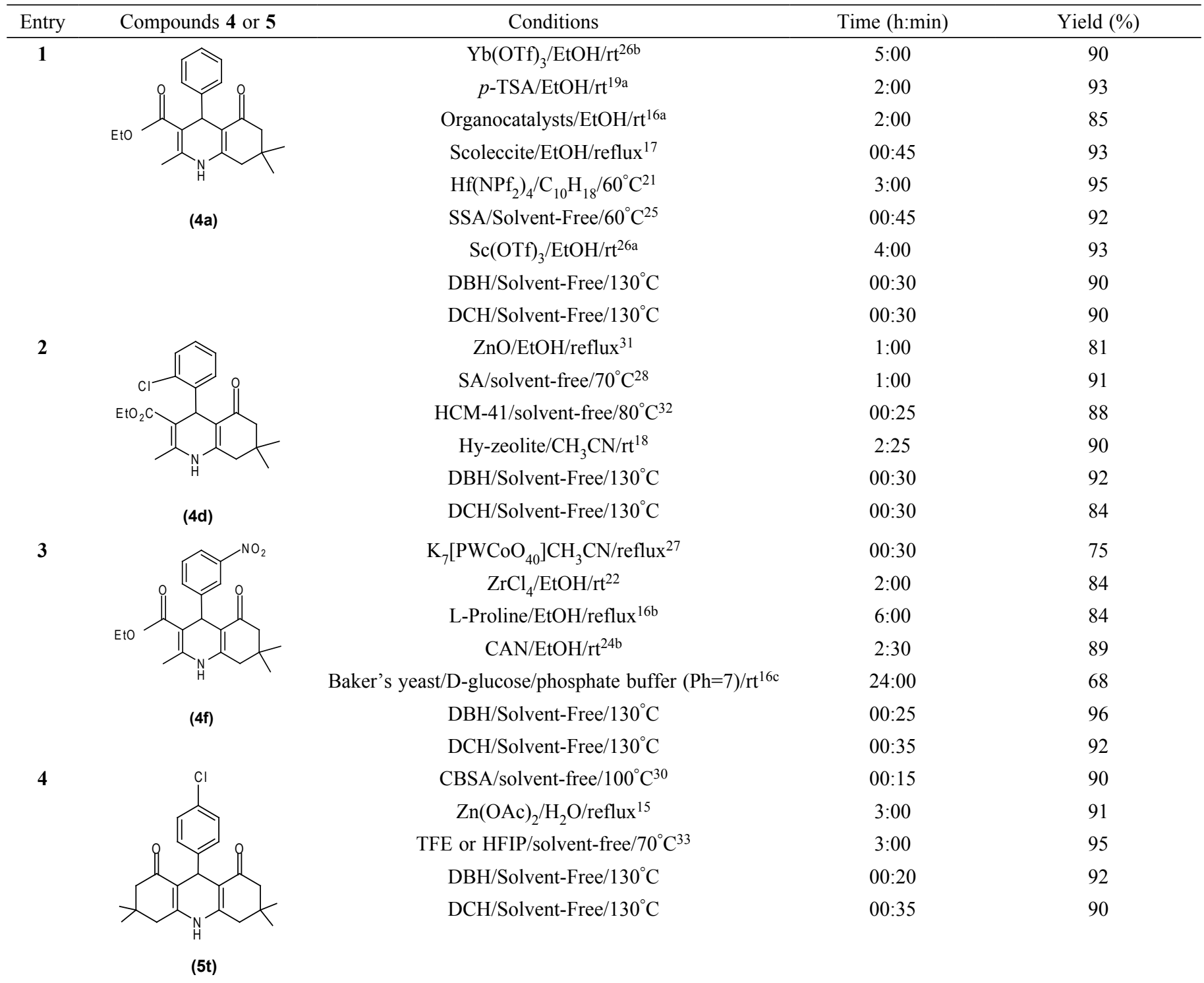

NMR $\left(75 \mathrm{MHz}, \mathrm{CDCl}_{3}\right) \delta 27.06,29.53,32.58,33.59,40.66$, $50.85,113.22,125.95,127.92,127.98,146.59,149.04,195.85$; IR ( $\mathrm{KBr}$ disc) $\mathrm{cm}^{-1}: 3233,3080,2965,1696,1602,1059$, 692.

\section{Acknowledgement}

The authors are grateful to research council Hakim Sabzevari University for financial support.

\section{References}

1. a) Orru, R. V. A.; De Greef, M. Synthesis 2003, 1471-1499 b) Balme, G.; Bossharth, E.; Monteiro, N. Eur. J. Org. Chem. 2003, 4101-4111 c) Domling, A.; Ugi, I. Angew. Chem. Int. Ed. 2000, 39, 3168-3210.
2. a) Webwr, L. Drug Discov. Today. 2002, 7, 143-147. b) Domling, A. Curr. Opin. Chem. Biol. 2002, 6, 306-313. c) Khurana, J. M. Nand, B. Saluja, P. Tetrahedron 2010, 66, 5637-5641. d) Jadidi, K.; Ghahremanzadeh, R.; Mirzaei, P.; Bazgir, A. J. Het. Chem. 2011, 48, 1014-1018. e) Shi, D. Q.; Ni, S. N.; Yang, F.; Ji, S. J. J. Het. Chem. 2008, 45, 1275-1280. f) Ghahremanzadeh, R.; Fereshtehnejad, F.; Yasaei, Z.; Amanpour, T.; Bazgir, A. J. Het. Chem. 2010, 47, 967-972. g) Shi, D. Q.; Ni, S, N.; Yang, F.; Shi, J. W.; Duo, G. L.; Li, X. L.; Wang, X. S.; Ji, S. J. J. Het. Chem. 2008, 45, 653-660. h) Ghassamipour, S.; Sardarian, A. R. J. Iran. Chem. Soc. 2010, 7, 237-242. i) Bolourtchian, M. J. Iran. Chem. Soc. 2010, 7, 269-274.

3. a) Sausins, A.; Duburs, G. Heterocycles 1988, 27, 269-289. b) Mannhold, R.; Jablonka, B.; Voigdt, B.; Schoenafinger, K.; Schraven, K. Eur. J. Med. Chem. 1992, 27, 229-235. c) Godfraid, T.; Miller, R.; Wibo, M. Pharmacol. Rev. 1986, 38, 321-416. d) Mager, P. P.; Coburm, R. A.; Solo, A. J.; Triggle, D. J.; Rothe, H. Drug Design Discovery. 1992, 8, 273-289.

4. a) Buhler, F. R.; Kiowski, W. J. Hypertens. 1987, 5, S3-10. b) Reid, J. L.; Meredith, P. A.; Pasanisi, F. J. Cardiovasc, Pharmacol. 1985, 7, S18-20. 
5. Klusa, V. Drugs Future. 1995, 20, 135-138.

6. Bretzel, R. G.; Bollen, C. C. Maeser, E.; Federlin, K. F. Am. J. Kidney Dis. 1993, 21, 53-64.

7. Bretzel, R. G.; Bollen, C. C.; Maeser, E.; Federlin, K. F. Drugs Future. 1992, 17, 465-468.

8. Boer, R.; Gekeler, V. Drugs Future. 1995, 20, 499-509.

9. Itoh, T.; Nagata, N.; Miyazaki, M.; Ishikawa, H.; Kurihara, A.; Ohsawa, A. Tetrahedron 2004, 60, 6649-6655.

10. a) Hantzsch, A.; Justus Liebgis Ann. Chem. 1882, 215, 1-2. b) Leov, B.; Snader, K. M. J. Org. Chem. 1965, 30, 1914-1920. c) Hantzsch, A. Dtsch. Chem. Ges. 1888, 21, 942-946 (d) Hantzsch, A. Dtsch. Chem. Ges. 1890, 23, 1474-1476.

11. a) Khadikar, B. M.; Gaikar, V. G.; Chitnavis, A. A. Tetrahedron Lett. 1995, 36, 8083-8086. b) Ohberg, L.; Westman, J. Synlett 2001, 1296-1298. c) Agarwal, A.; Chauhan, P. M. S. Tetrahedron Lett. 2005, 46, 1345-1348. d) Muscia, G. C.; Buldain, G. Y.; Asis, S. E. Monatsh. Chem. 2009, 140, 1529-1532. e) El Ashry, E. S. H.; Awada, L. F.; Ibrahim, E. S. I.; Bdeewy, O. K. Arkivoc 2006, ii, 178-186. f) Tu, S. J.; Zhou, J. F.; Deng, X.; Cai, P. J.; Wang, H.; Feng, F. C. Chin. J. Org. Chem. 2001, 21, 313-316 g) Tang, Z.Q.; Chen, Y.; Liu, C. N.; Cai, K. Y.; Tu, S. J. J. Het. Chem. 2010, 47, 363-367.

12. Maheswara, M.; Siddaiah, V.; Damu, G. L. V.; Rao, C. V. Arkivoc 2006, ii, 201-206.

13. Ko. S.; Sastry, M. N. V.; Lin, C.; Yao, C. F. Tetrahedron Lett. 2005, 46, 5771-5774.

14. a) Ji, S. J.; Jiang Z. Q.; Lu, J.; Loa, T. P. Synlett 2004, 831-835. b) Sridhar, R.; Perumal, P.T. Tetrahedron 2005, 61, 2465-2470.

15. Balalaie, S.; Chadegani, F.; Darvich, F.; Bijanazadeh, H. R. Chin. J. Chem. 2009, 27, 1953-1956.

16. a) Kumar, A.; Maurya, R. A. Tetrahedron 2007, 63, 1946-1952 b) Karade, N. N.; Budhewar, V. H.; Shinde, S. V.; Jadhav, W. N. Lett. Org. Chem. 2007, 4, 16-19 c) Kumar, A.; Maurya, R. A. Tetrahedron Lett. 2007, 48, 3887-3890.

17. Gadekar, L. S.; Katkar, S. S.; Mane, S. R.; Arbad, B. R.; Lande, M. K. Bull. Korean Chem. Soc. 2009, 30, 2532-2534.

18. Das, B.; Ravikanth, B.; Ramu, R.; Rao, B. V. Chem. Pharm. Bull. 2006, 54, 1044-1045.

19. a) Cherkupally, S. R.; Mekala, R. Chem. Pharm. Bull. 2008, 56, 1002-1004. b) Kumar, A. Maurya, R. A. Synlett 2008, 6, 883-885. c) Kumar, A.; Sharma, S.; Tripathi, V. D.; Maurya, R. A.; Srivastava, S. P.; Bhatia, G.; Tamrakar, A. K.; Srivastava, A. K. Bioorg. Med. Chem. 2010, 18, 4138-4148.

20. Song, G.; Wang, B.; Wu, X.; Kang, Y.; Yang, L. Synth. Commun. 2005, 35, 2875-2880.

21. Hong, M.; Cai, C.; Yi, W. B. J. Fluorine Chem. 2010, 131, 111114.

22. Reddy, C. S.; Raghu, M. Indian J. Chem. 2008, 47B, 1578-1582.

23. Su. W.; Li, J.; Li, J. Aust. J. Chem. 2008, 61, 860-863.

24. a) Ko, S. K; Yao, C. F. Tetrahedron 2006, 62, 7293-7299. b) Reddy, C. S.; Raghu, M. Chin. Chem. Lett. 2008, 19, 775-779.

25. Mobinikhaledi, A.; Foroughifar, N.; Bodaghifard, M. A.; Moghanian, H.; Ebrahimi, S.; Kalhor, M. Synth. Commun. 2009, 39, 1166-1174.

26. a) Donelson, J. L.; Gibbs, R. A.; De, S. K. J. Mol. Catal. A: Chem. 2006, 256, 309-311. b) Wang, M. L.; Sheng, J.; Zhang, L.; Han, W. J.; Fan, Y. Z.; Tian, H.; Qian, C. T. Tetrahedron 2005, 61, 1539-1543.

27. Heravi, M. M.; Bakhtiari, K.; Javadi, N. M.; Bamoharram, F. F.; Saeedi, M.; Oskooie, H. A. J. Mol. Catal. A: Chem. 2007, 264, 50-52.

28. Foroughifar, N.; Mobinikhaledi, A.; Bodaghifard, M. A.; Moghanian, H.; Ebrahimi, S. Synth. React. Inorg. Metal-Org. Nano-Metal Chem. 2009, 39, 161-164.
29. Mekheimer, R. A.; Hameed, A. A.; Sadek, K. U. Green. Chem. 2008, 10, 592-593.

30. Davoodnia, A.; Khojastehnezhad, A.; Tavakoli-Hoseini, N. Bull. Korean Chem. Soc. 2011, 32, 2243-2248.

31. Matloubi Moghaddam, F.; Saeidian, H.; Mirjafary, Z.; Sadeghi, A. J. Iran. Chem. Soc. 2009, 6, 317-324.

32. Nagarapu, L.; Kumari, M. D.; Kumari, N. V.; Kantaveri, S. Catal. Commun. 2007, 8, 1871-1875.

33. Heydari, A.; Khaksar, S.; Tajbakhsh, M.; Bijanzadeh, H. R. J. Fluorine Chem. 2009, 130, 609-614.

34. a) Veisi, H.; Ghorbani-Vaghei, R. Tetrahedron 2010, 66, 74457463. b) Kolvari, E.; Ghorbani-Choghamarani, A.; Salehi, P.; Shirini, F.; Zolfigol, M. A. J. Iran. Chem. Soc. 2007, 4, 126-174. c) Maleki, B.; Gholizadeh, M.; Sepehr, Z. Bull. Korean Chem. Soc. 2011, 32, 1697-1702. d) Veisi, H.; Gholbedaghi, R.; Malakootikhah, J.; Sedrpoushan, A.; Maleki, B.; Kordestani, D. J. Het. Chem. 2010, 47, 1398-1405. e) Ghorbani-Vaghei, R.; Azarifar, D.; Khazaei, A.; Maleki, B. Phosphorus, Sulfur, and Silicon, 2004, 179, 1877-1881. f) Veisi, H.; Ghorbani-Vaghei, R.; Zolfigol, M. A. Org. Prepar. Proc. Int. 2011, 43, 489-495.

35. a) Zolfigol, M. A.; Nasr-Isfahani, H.; Mallakpour, S.; Safaiee, M. Synlett. 2005, 5, 761-764. b) Pu, Y. M.; Christesen, A.; Ku, Y. Y. Tetrahedron Lett. 2010, 51, 418-421. c) Hojati, S. F.; Gholizadeh, M.; Haghdoust, M.; Shafiezadeh, M. Bull. Korean Chem. Soc. 2010, 31, 3238-3240. d) Khazaei, A.; Amini Manesh, A. Synthesis 2005, 12, 1929-1931. e) Azarifar, D.; Nadimi, E.; Ghanbari, M. M. Chin. Chem. Lett. 2011, 22, 447-450.

36. Markish, I.; Arrad, O. Ind. Eng. Chem. Res. 1995, 34, $2125-$ 2127.

37. Tilstam, U.; Weinmann, H. Org. Process Res. Dev. 2002, 6, 384393.

38. (a) Mirjalili, B. F.; Bamoniri, A.; Akbari, A.; Taghavinia, N. $J$. Iran. Chem. Soc. 2011, 8, S129-S134. b) Ghorbani-Vaghei, R.; Malaekehpoor, S. M. J. Iran. Chem. Soc. 2010, 7, 957-964. c) Zare, A.; Khanivar, R.; Hatami, M.; Mokhlesi, M.; Zolfigol, M. A.; Moosavi-Zare, A. R.; Hasaninejad, A.; Khazaei, A.; Khakyzadeh, V. J. Mex. Chem. Soc. 2012, 56, 389-394. d) Tajbakhsh, M.; Hosseinzadeh, R.; Rezaee, P.; Alinezhad, H. J. Mex. Chem. Soc. 2012, 56, 402-406.

39. a) Azarifar, D.; Maleki, B.; Setayeshnazar, M. Phosphorus, Sulfur, and Silicon, 2009, 184, 2097-2102. b) Maleki, B. Coll. Czech. Chem. Commun. 2011, 76, 27-37. c) Maleki, B.; Azarifar, D.; Hojati, S. F.; Gholizadeh, M.; Viesi, H.; Salehabadi, H.; Khodaverdian Moghadam, M. J. Het. Chem. 2011, 48, 449-453. d) Maleki, B.; Veisi, H. Bull. Korean Chem. Soc. 2011, 32, 43664370. e) Maleki, B.; Salehabadi, H.; Sepehr, Z.; Kermanian, M. Coll. Czech. Chem. Commun. 2011, 76, 1307-1315. f) Maleki, B.; Tayebee, R.; Sepehr, Z.; Kermanian, M. Acta Chim. Slov. 2012, 59, 814-823. g) Mohammadi, A.; Keshvari, H.; Sandaroos, R.; Maleki, B.; Rouhi, H. Moradi, H.; Sepehr, Z.; Damavandi, S. Appl. Catal. A: Gen. 2012, 429-430, 73-78. h) Veisi, H.; Vafajoo, Z.; Maleki, B; Maghsoodlou, M. T. Phosphorus, Sulfur, and Silicon, 2013, 188, 672-677.

40. a) Maleki, B.; Azarifar, D.; Ghorbani-Vaghei, R.; Veisi, H.; Hojati, S. F.; Gholizadeh, M.; Saleabadi, H.; Khodaverdian Moghaddam, M. Monatsh. Chem. 2009, 140, 1485-1488. b) Veisi; H.; Amiri, M.; Hamidian, A. H.; Malakootikhah, J.; Fatolahi, L.; Faraji, A.; Sedrpoushan, A.; Maleki, B.; Ghahri Saremi, S.; Noroozi, M.; Bahadoori, F.; Veisi, S. Phosphorus, Sulfur, and Silicon, 2010, 185, 689-696. c) Azarifar, D.; Zolfigol, M. A.; Maleki, B. Bull. Korean Chem. Soc. 2004, 25, 23-27 d) Hojati, S. F.; Mohammadpoor-Baltork, I. Maleki, B.; Gholizadeh, M.; Shafiezadeh, F.; Haghdoust, M. Can. J. Chem. 2010, 88, 135-141. e) Azarifar, D.; Zolfigol, M. A.; Maleki, B. Synthesis 2004, 11, 1744-1747. 